\title{
Bashkir Onomatology in the Light of Modern Linguistics
}

\author{
Munir Idelovich Karabaev \\ 453103, Republic of Bashkortostan, Sterlitamak, 49 Lenina Ave, Office 216 \\ Email:munir.karabaev@yandex.ru \\ Gulfira Rifovna Abdullina \\ Zulfiya Karimovna Ishkildina
}

Sterlitamak branch of Bashkir State University, Sterlitamak, Russian Federation

(453103, Sterlitamak, 47a Lenin Avenue)

\section{Doi:10.5901/mjss.2015.v6n3s3p73}

\begin{abstract}
Onomatology is considered one of the well-studied areas in Bashkir linguistics. However, there are a number of issues requiring specification and refinement. Thus, today there is no consideration and study in monographic sense for such categories of Bashkir onomatology as cosmonyms, zoonyms, mythonyms, phytonyms, urbanonyms, and nicknames. The role of onomastic units in the creation of the Bashkir language picture of the world is not defined either. This paper, because of an integrated approach to the study of onomastic space of the Bashkir language, revealed general and specific features of onomastic units of the above categories. In particular, lexical and conducted genetic analysis and derivation of Bashkir personal names and nicknames; given the highest priority of zoonymic vocabulary; the paper examines lexical-semantic features of phytonyms; it suggests lexical-semantic description of urbanonyms; and studies features of the trans-onymization process in the onomastic system of the Bashkir language.
\end{abstract}

Keywords: the Bashkir language, onomatology, anthroponym, zoonym, phytonym, urbanonym, ornithonym, godonym.

The study was conducted under the "Urbanonyms in the onomastic space of the Bashkir language" grant, provided by Sterlitamak Branch of the Bashkir State University.

\section{Introduction}

Onomastic lexicon contains not only the facts of language, but also carries cultural and historical information on other aspects of society. Therefore, onomastic units for many years do not cease to be at the centre of research interest for both linguists and historians, anthropologists, geographers, and archaeologists. This interest is explained by the desire of using the borrowing not only to learn the language and its history, but the history of the people, their ethnic and cultural development; Many questions of Bashkir onomatology today are clarified and described in detail by T. Kh. Kusimova (2005), F. G. Khisamitdinova (2006), R. A. Suleimanova (2006), toponymy is studied in the papers by A. A. Kamalov (1994), R. Z. Shakurov (1986), M. G. Usmanova (1994), R. A. Sirazhitdinov (2000), et. al. However, onomatology, like all science, does not stay in place, but is developing. Its development features with new questions arising, which are waiting for answer. In addition, urgent problems emerge, requiring immediate solution. An integrated approach to the study of onomastic space can answer many questions and help address the key challenges in this field of linguistics, identify common and specific features of onomastic units of different rank. Thus, today there is no consideration and study for such categories of Bashkir onomatology as cosmonyms, zoonyms, mythonyms, phytonyms, urbanonyms, and nicknames. The role of onomastic units in the creation of the Bashkir language picture of the world is not defined either. The absence of a comprehensive study in the Bashkir linguistics for the onomastic space of the Bashkir language predetermined the goal of this work.

The following objectives are put forward in order to solve the goal:

a) A comprehensive review of the Bashkir onomatology, identifying its specific character;

b) Lexical and word-formation and genetic analysis of the Bashkir personal names and nicknames;

c) Analysis of the zoonymic vocabulary in the Bashkir language;

d) Lexical-semantic analysis of phytonyms;

e) Lexical-semantic description of urbanonyms;

f) Identification of the trans-onymization process in the onomastic system in the Bashkir language. 


\section{Literature Review}

Bashkir onomatology on a truly scientific basis started to flourish with the 70-ies of XX century. This is the period when there appeared articles and books of scientific and popular character on various issues of onomatology. In 1967 - 1974 years, the cities of Ulyanovsk, Ufa, Gorky, Saransk, Penza held five conferences on onomatology of the Volga region. During this period there were published the papers by R. G. Kuzeev, T. M. Garipov, T. Kh. Kusimova, Dzh. G. Kiekbaev, A. A. Kamalov, R. Z. Shakurov, Z. G. Uraksin, F. G. Khisamitdinova, et. al. The works of the above-mentioned linguists reflect the results of studies on anthroponomy, toponymy, and zoonymy. Now, in the early XXI century, the researches on Bashkir onomatology are continued. The thesis paper by R. Ya. Khalitov "Hydronyms of the Orenburg region" is devoted to the study of names of bodies of water in the Orenburg region. Hydronyms are examined in the following aspects: principles of the nomination of water bodies, sources of names, structural features of word-formation for hydronyms. R. Ya. Khalitov highlights the components that define the attributes of objects in colour, volume, shape, and depth in complex hydronyms. For example: colour of the object: Акбулак, ак'white'; Каракүл, кара'black'; depth: Тәрән күл, тәрән'deep'; haй, haй'shallow' (Khalitov, 2002).

L. A. Lasynova in her work analyses the oronyms of the southeast Bashkortostan on lexical-semantic, genealogy and morpheme-word-formation characteristics. The author highlights two main groups of oronyms by lexical-semantic features: 1. Oronyms reflecting properties of natural objects. 2. Oronyms pointing to economic and ideological activities of people. The scientist examining linguistic affiliation oronyms concludes that the southeast Bashkortostan features with the ethnic relations of following nature: Iranians-Turkomans, Finno-Ugric-Turkomans, Mongols-Turkomans, and RussianBashkirs (Lasynova, 2004).

Rich scientific information on the Bashkir anthroponomy can be found in the book by T. Kh. Kusimova and $\mathrm{S}$. A. Bikkulova "Башкорт исемдәре 'Bashkir names'". In this paper, Bashkir names are divided into 20 groups on lexicalsemantic features. Here are some of them: names reflecting the external features of the child and the physical properties, such as the word миң'birthmark': Миңһылыу, Миңлебай; names reflecting time-pertaining events: Айhылыу, Таңһылыу, Таңатар; ай'moon', таң 'dawn'; names reflecting the conditions when the child was born: Яубатыр, Байрамбикә; яy'raid','battle' and байрам'celebration'; names reflecting colours: Акбатыр, Карабай; ак'white', кара'black'; names formed based on the denominations of plants and flowers: Муйылбикә, Имәнбай; муйыл'hackberry', имән'оak' (Kusimova and Bikkulova, 2005).

Bashkir mythotoponyms and individual mythonims are reflected in the lexicographical work by G. Kh. Bukharova, "Bashkir onomatology in the context of spiritual culture. Dictionary of mythotoponyms". The author describes not only the area of distribution of mythotoponyms, but discusses the issues of their etymology (Bukharova, 2006).

Interesting materials on Bashkir anthroponomy can be found in the paper by F. G. Khisamitdinova and S. Kh. Tupeev "Төрки сығанаклы һәм төрки элементлы башкорт исемдәре'Bashkir names of Turkic origin'". This paper determines the meanings of Turkic names, interprets each component of complex anthroponyms. For example, Абдулхан - абдул, the Arab word meaning 'servant', 'servant of God;'perpetual companion' + хан, а Turkic and Mongolian title (Khisamitdinova and Tupeev, 2006).

The work on toponymy by R. Z. Shakurov "On the trails of geographical names" is aimed at the study of geographical objects of the basin of the Dema River of the Republic of Bashkortostan. The author in his work produces lexical-semantic, lexical, and genetic analysis and derivation of Bashkir names. R. Z. Shakurov concludes that the names of geographic features are directly related to the practical activities of people, toponyms arouse from the needs of society; they serve these needs and, therefore, reflect all aspects of reality (Shakurov, 1986).

Bashkir ethnonyms are studied in the candidate thesis paper by R. A. Sirazhitdinov. The author pays special attention to scientific research, which put forward the different versions of the origin of the ethnonym башкорт'башкир'. R. A. Sirazhitdinov, producing a thorough review of the linguistic literature, concludes that the most convincing is the hypothesis by N. V. Bikbulatov, who connects the ethnonym башкорт with the anthroponym Башкорт. From the point of view of semantics, Bashkir ethnonyms, according to scientists, are divided into the following groups: a) ethnonyms going up to zoonyms; b) ethnonyms going up to phytonyms; c) ethnonyms going up to anthroponyms; d) ethnonyms going up to the social and material terms; e) numerical ethnonyms. The author believes that the most ancient are totem ethnonyms associated with ancient mythical representations of the Bashkirs (Sirazhitdinov, 2000).

According to a brief review of the literature on the Bashkir language onomatology, one can draw some conclusions, that this field of Bashkir linguistics is developing dynamically; a lot of monographs are published and thesis are defended devoted to different sections of onomatology. 


\section{Methodology}

Systematic study of onomastic space of the Bashkir language uses descriptive and historical methods, and the elements of analysis and synthesis. Descriptive method was used in the collection and cataloguing, as well as in the systematization of linguistic material. Using this method, the onomastic units were divided into species and types. The historical approach to the study of onomastic space revealed the linguistic identity of onyms, showed the connection of the onomastic units to the history and culture of the people. In addition, the historical method allowed for determining the correlation of certain phenomena of Bashkir onomatology with a particular period in the life of society. Using the method of analysis revealed morphemic structure and word-formation characteristics of onomastic units and clarified the productive derivational formants. The results can contribute to the development of descriptive lexicology. Some of the findings may be used in the study of historical grammar of the Bashkir language, linguistics, and ethnography of the Bashkirs. The practical significance of this study is that the results can be claimed in the preparation of general and specific dictionaries, articles materials can be used in research works on onomatology and ethnography.

\section{Results}

\subsection{Bashkir anthroponomy}

Despite the availability of research in various areas of the Bashkir onomatology, some problems require in-depth and comprehensive study.

Modern Bashkir anthroponomy is represented by such onyms as personal names, nicknames, and pseudonyms. Bashkir names contain language materials from not only the Turkic language family, but also from the Semitic and IndoEuropean families of languages. Despite the wide representation of foreign lexemes in the Bashkir anthroponomy, fixed assets is comprised of personal names made of, according to T. H. Kusimova, native Bashkir words that are associated with the ancient traditions of naming. Traces of animistic worldview preserved in the names associated with the spiritualization of natural phenomena, celestial bodies, with the names of animals and totems (Kusimova and Bikkulova, 2005). The oldest are the names that reflect the outward signs of the child. For example, children born with a caul received names with the component of йөз̆face', 'image': Йөзлөбай - luzlubai, Йөзлөбикә - luzlibika. Some of the names point to the time, when the child was born. The components of such names are көн 'day', төн 'night', ай 'moon', кояш 'sun', таң 'dawn'. For example: Айгөл - Aigul, Айтуған - Aitugan, Көнһылыу - Kunsulu. In many ways it is reflected semi-nomadic Bashkir way of life. The composition of such composite names features with the words юл'way', 'route', күсеу'transmigrate': Юлдаш - Iuldash, Юлдыбай - Iuldybai, Юламан - Iulaman, Күсем - Kuchim, Күсәрбай Kucherbai. The system of Bashkir names has names-amulets. Ancient Bashkirs believed in the magical power of words and thought that the "safety names" are the way to save the child. For example: Торһон - Tursun, Торһонғужа Tursunguzha, Үлмәс̧бай - Ulmasbai, Үлмәсббикә - Ulmasbika, Ис̧әнбай - Isianbai, Ис̧әнғол - Isiangul, in which the components are the following words mop 'to live', үлмәсс'will not die', ис̧ән 'unharmed', 'alive'.

The Bashkirs life is closely connected with nature, wildlife. Many of the qualities of animals and birds have motivated the use of animal names in the consecration. Names submitted by the names of animals, are widely used by the Bashkirs. For example: Арысланбай, Арысллан, Арысланбикә: арысллан'lion', Һандуғас: hандуғас'nightingale', Карлуғас: карлуғас'swallow', Бүребай: бүре'wolf'.

The second group of Bashkir names in words borrowed from the Arabic, Persian, Mongolian, Russian, Hebrew languages, as well as European languages. As it is known, VII - X centuries in Central Asia were marked by wide usage of the Arabic language as a language of educated and religious people, while the Persian language was used as a literary language in Seljuk state, and for the majority of the peoples of the East it started to serve as a language of poetry and prose. During this period, the Arab and Persian languages were spreading and encountered the Turkic language. As a result, the Turkic languages were filled with the words from the Arab and Persian languages. As the analysis of Arab names shows, first borrowed names were the names of the prophets. For example: Мөхәммәm - Mukhammet, ИзрисIdris, Ильяс - llias, Йocon (Йоcoф) - lusuph. However, it is impossible to explain the circumstances of penetration of Arab names only by the influence of Islam. Many of borrowed Arab names belong to the sphere of science and education, and they penetrated in Turkic languages under their influence. For example: Ғәлим - Galim, Ғилминиса Gilminisa: ғилем'science'; Азамат - Azamat: азамат - бөйөк, мәшhyp'great, mighty'; Вәлиулла - Valiulla: вәли укымышлы'noble', Мәғриф - Magrif: магриф - аңлы, белемле 'clever', 'educated'. A separate group of Arab names goes back to the words for different qualities of the person: Рәфил - Rafil; рәфиил - купшы'neat', Рәхим - Rakhim; рәхим - мәрхәмәтле'kind', 'virtuous', Сәхи - Sakhi; сәхи - киң күңелле, йомарт'generous', Вәзиғә - Vaziga; 
вәзиғә - тыйнажлы, бас̧алкы'humble', Йәмилә - Yатіlya; ямиля - бик матур'very beautiful'. Some of Arab names are the synonyms to Bashkir names. For example: Bashkir name Арысулан - Arslan, Arab names - Хәйз̧әр - Khaidar, Кәнзәфәр - Kanzafar, Әсәдулла - Asadulla go up to the word lion; Bashkir name - Юлдаш - Yuldash, 'companion', Arab name - Сәфрәр - Safar, 'way'. The same semantic phenomena are observed among the Persian borrowings. Some words are the synonyms to Arab and Bashkir names. For example: Aйhылыу - Aisulu, Көнhылыу - Kunsulu; көн 'day', 'sun', aŭ'moon', 'night' - are Bashkir names, Кәмәр - Kamar'like the Moon', Шәмсиә - Shamsiya'like the Sun'- are Arab names, Маһия - Makhiya 'like the Moon' - is Persian name. Persian names feature with words connected to the concept of beauty: Гөлбикә - Gulbika, Гөлнур - Gulnur, Гөлзифра - Gulzifa.

Borrowings from the Mongolian language are common for the composition of Bashkir anthroponyms. T. Kh. Kusimova believes that the name Aŭpam Airat goes up to the Mongolian ethnonym oŭpom - the name of a tribe, Сыңғыз - Chigiz'strong, great', Колғона - Kulguna 'mouse' (Kusimova and Bikkulova, 2005).

Hebrew words that occur in the Bashkir language, mostly related to theonyms. For example: Ибpahuм - Abraham, мyса - Moses, Исхак - Isaac, Сөләймән - Solomon.

When analysing the linguistic identity of the Bashkir names, it can be stated that there is a reverse borrowing. For example, N. A. Baksakov, analysing the etymology of the Russian names, comes to the conclusion, that the family name Karamyshev goes up to the Turkic word горумус'warder' or гарумус'got older', and anthroponym Kochubei consists of a composition of Turkic words кесе бeŭ'younger bey'. Family name Tatarinov goes up to the Turkic ethnonym mamapuн Tatarian, family names Shishkin and Shishkov are formed from the root mem'tumor' (Baskakov, 1979).

In recent years, there has been frequent use of European names in the Bashkir anthroponymic system. This group includes the following names: Albert, Oliver, Oscar, Marseille, Marat, Louise, Diana, Sofia, Ilmira, Eleanor, Clara, and Jeanne. There are facts of naming with incomplete forms of borrowed names. For example: Margarita - Rita, Edward Edik, Vladislav - Vladik (Suleimanova, 2006).

Thus, Bashkir anthroponomy is developing and being enriched using internal resources, as well as borrowed words.

\subsection{Bashkir family names}

As it is known, the Turkic peoples, including the Bashkirs, did not use family names. If necessary, nicknames or pseudonyms were used instead of family names. Usually people were named with the following scheme: name + father's name + kinship terms кыззы'daughter' or уль'son'. For example, Арысулан Бикмәт уль'Arslan, the son of Bikmet', Мәликә Солтанбай кызы 'Malika, the daughter of Sultanbai'. In historical documents of the XVII century, the Bashkirs are listed with the family names. Bashkir family names were created in the same way, as Russian family names, and the formants were the same linguistic resources, as well as for Russian family names. The functions of the names were names or nicknames, ethnonyms and names of geographic objects. For the purposes of the general passporting, according to T. M. Garipov, children, especially boys, instead of the family names, used their father's name. For example, Шәкир Кәримович Кәримов 'Shakir Karimovich Karimov', while the son of Shakir, i.e. the grandson of Karim will have the name Зәкир Шәкирович Шәкиров 'Zakir Shakirovich Shakirov' (Garipov, 1976). Thus, the names of close relatives were not the same; they changed from generation to generation. Bashkirs family names in their present form began to take shape in the XVII century.

Their basis was personal names, and by adhering of suffixes of the Russian language, to personal names, mainly to male names, the family names are formed. In this process, the following suffixes are actively used:

1) If the name ends in a consonant phoneme, then it is necessary to add the suffix of -ов (-ова): Сәлим Сәлимов, Ғафрар - Ғафраров, Tahup - Tаһupoв; if the phoneme ob is in the end of the name, then op alternates with the phoneme $n$ when forming family names. It means that in this case we can observe the following morpho-phonological phenomenon:

Йософ - Йосопов, Ғариф - Ғарипов, Зариф - Зарипов, Шәриф - Шәрипов, Латиф - Латипов (Abdullina, 2004);

2) If the name ends in $u$, ьıй, $m$, then it is necessary to add the suffix of -ев (-ева): Мәһәз̧и - Мәһәз̧иев, Нәби - Нәбиев, Барый - Барыев, Бикташ - Бикташев;

3) If the root ends with vowels, then it is necessary to add the suffix of -ин (-ина):

- The formation of the family names features with falling out of the phoneme $b, \partial, e, b$ in the end of the name: Ғайса - Ғайсин, Туйсы - Туйсин, Ишкилде - Ишкилдин, Сафра - Сафин;

- If there is the component -улла in the name, then the phoneme a falls out at forming family names: Абдулла - Абдуллин, Хәмизуулла - Хәмизууллин, Хәйбулла - Хәйбуллин. 
Thus, in the process of formation of the Bashkir language, family names are formed at a certain law. In this process, productive formants are the suffixes of the Russian language (Ishbaev et al., 2006).

\subsection{Bashkir nicknames}

As it is known, nicknames function as an informal person's name. A human being does not choose own nickname, just as the personal name. Nicknames usually exist within a micro society (a group of people working or studying together, the residents of a village, a group of young people) and used in the language of this group. They, in contrast to personal names, indicate the actual features and qualities of the person, as the most frequent reasons for their occurrence are bright and individual features called (Karabaev, 2008).

Nicknames in the Bashkir language in its lexical and semantic features, word features, and lexical-genetic sources are divided into several groups.

Based on empirical data, the Bashkir language has the following lexical-semantic groups of nicknames:

1) ornithonyms: Tауык'Chicken', Турғай'Sparrow', Торна'Crane', Ceneŭ'Nestling', Kарға'Crow', hайыс̧жан'Magpie';

2) names of animals: Куян 'Hare', Йомрандар 'Gophers', Бесәй 'Cat', Aйыу'Bear', Төлкө'Fox';

3) names of domestic animals: Кәзә'Goat', Бәрәс'Goatling', Сускалар'Pigs', Ишәк'Donkey';

4) names of other animals: Мaймыл'Monkey', Бака'Frog', Дөйә'Camel';

5) names of the professions and crafts: Агроном - Agriculturist, Шағир 'Poet', Сәсән'Sesen';

6) military terms Комбат - Kombat (Battalion commander), Пехота - Pekhota (Infantry), Полковник - Polkovnik (Colonel), hалдаm'Soldat' (Soldier), Эскадрон - Eskadron (Squadron), 9-я poma - Devyataya rota (9th troop), Танкист - Tankist (Tanker);

7) ethnonyms: Eврей - Evrei (Jew), Tamap'Tatarian', Cыуyаw'Chuvash', Немец - Nemets (German), Яnон'Japanese';

8) names of different characters: Чебурашка - Cheburashka, Дед Мазай - Ded Mazai, Камыр - Batyr, Шурик Shurik;

9) anthroponyms: Шаляпин - Shalyapin, Ленин бабай - Lenin babai, Чапай - Chapay, Гагарин - Gagarin;

10) names of food items: Kaтыı'Qatiq', Бал'Ноnеy', Билмән 'Ravioli';

11) shortcut names, their concord: Фәнтүк - Fanil, Шәпүк - Shafkat, Әпүк - Alfinur, Әnuc - Rafis, Әүес Rauf, Хәйбуш - Khaibulla, Таска - Taskira;

12) mimetic or emotionally expressive words: Мыр-мыр - Ilmir, Уфp - Rauf, Xu-Xu - Khisametdin;

13) abbreviations: ДПC - DPS (Traffic police), ЧП - ChP (Incident), АКШ 'USA'.

14) mythonyms: Бапак'Buka', Бәреŭ'Devil', Шаŭmaн - Shaitan.

Thus, the function of nicknames is presented by the words of different lexical-semantic group. When analysing the morphemic structure and word-building features nicknames, the following facts may be allocated:

- the majority of the nicknames are formed using the root of the words: Mыйыз'Moustache', Kьяр 'Cucumber', Сүкеш'Наmmer', Себен'Fly';

- there are nicknames formed using two root morphemes: Һәғилә әбей'Grandma Sagilya', Тайыщ бабай'Bandy-legged old man', Мунса ташы'Bathing stone', Ауыл ене'Village devil', Урман Зифраһы'Forest Zifa', Матур малай'Handsome boy'.

Morphemic composition of anthroponyms of this category has the suffixes from the Russian language. For example, Уяу'Watchful', Уяучик (his) son, Азик - Azamat.

Lexical composition of these nicknames is heterogeneous. Their structure contains units that do not meet the standards of literary language. The abundance of dialect in their composition is a natural phenomenon, because nicknames are the result of creative thinking of the locals. Function of nicknames is performed by the following dialect words: Песләк'running eyes', formal language: йәшле - Niyaz, Тәкәрлек'wagtail', formal language: ак сәпсек - Radik, Бүкәй'bugaboo', formal language: бокай, which scare children - Fail, Кәпәй 'whirled up', formal language: күпкәк Khalil, Сапакай'babbler', formal language: телсәр - Askat, Абағай 'nimble', formal language: теремек - Gulnur, Шәnәmə'negligent', formal language: hənpə - Shaikber. A separate group of nicknames relates to borrowings and goes up to the Russian language or through the Russian language to the European languages: for example, Globe - Fanur, Child prodigy - Gali, Shop - Nafisa, Yurka - Yunir, Cocaine - Ildus, Goomba - Rafkat, Bourgeois - Radzhap, Kolkhoz Fanil, Kuzya - Artur, Phosphorus - Ildar, Yakudza - Vadim.

In some cases, the appearance of nicknames motive is personal attitude to the properties referred to, that is, the modality is observed. The modality can be expressed by different grammatical means. For example, the nicknames 
Зөпөк, Әуес, Фәнтүк, Шәпүк translate the modality using formants, common for vernacular language -nөк, -үec, $п ү к$. In addition, the modality can be expressed in the semantics of the word itself, which serves as a nickname. This provision is clearly expressed in the following examples: Орсож'Spindle' - Rosalia, Бурз̧ай'Dog' - Milingul, Тыртайған'Offended, miffed' - Dinara, Tарамыш'Thin' - Anur, Taз̧'Lousy' - Ramil. As it is shown by the actual materials, many nicknames express an emotional relationship, that is, delight, mockery and irony to the properties of the nickname's carrier (Башкорт теле, 2012).

Thus, nicknames have a special place in anthroponymic system of the Bashkir language. The peculiarity of this onyms is expressed in the following:

- A nickname is usually associated with one person;

- They function as an informal name;

- The words included in this section anthroponomy by lexical composition are heterogeneous in their composition; there are dialect, jargon and lexemes, pertaining to different stylistic groups;

- Nicknames have some relevance to folklore, as they are the result of word creation of the local population.

\subsection{Pseudonyms}

Pseudonym is the fictitious name of people engaged in creative activities - writers, artists, journalists, and in some cases, politicians. Unlike other anthroponymic units, pseudonyms are chosen by its carrier and at their wish. Another difference of the pseudonyms from the nicknames is their official status. Bashkir writers and scientists for a long time attached to their personal or last names the name of the tribe, birth, nationalities and used them as pseudonyms. For example, Ғәбдрәхим Усман әл-Болғари,Тажетдин Ялсығол әл-Башкорди. In some cases, pseudonyms point to the place of birth or residence of its carrier: Төхвәт Йәнәби, Муса Ғәли, Сәйфи Уфралы. Personal name may be used as a pseudonym: Ғ. Сәләм (Galimov Salyam), М. Хәй (Mukhamediarov Khai); folk character: Кирәй Мәргән (Akhnaf Kireev); shortcut name: Али Карнай (Gali Zulkarnaev).

In some cases, a nickname given by others gradually begins to function as a pseudonym. For example: Акмулла (Miftakhetdin Kamaletdinov), Йәрми Сәйете (Sait Ismagilov), Байык Aйзар (Bikmukhamet). Writers often use several pseudonyms: Мәжит Ғафури - Шәмғун, Ласин; Шәйехзада Бабич - Шөпшә, Каяу; Булат Ишемғол - Булат, Таң, Кәләм, Серекәй. Modern writers used the shorcut family names type as a pseudonym: Әхиәр Хәким - Әхиәр Хәкимов, Нәжип Из̧елбай - Нәжип Из̧елбаев (Bashkortostan, 1997).

Thus, pseudonyms in the Bashkir language are often used by representatives of creative professions.

\subsection{Bashkir zoonymy}

Zoonymy is a poorly studied area of the Bashkir onomatology. Some questions related to Bashkir zoonymy were covered in the papers by such scientists as T. G. Baishev (Baishev, 1952), E. F. Ishberdin (Ishberdin, 1986), and Z. G. Uraksin (Uraksin, 1976).

Horses' names are the most common in the Bashkir language. This is because the horse was and is a reliable companion of the Bashkirs throughout their life. Not a single event is complete without the participation of horses: household activities, holidays and fun, and, until recently, even wars.

Z. G. Uraksin, having analysed the names of horses, comes to the following conclusion (Uraksin, 1976).

Many names are directly connected to the features of the animals:

- colour of a horse: Ерән 'Ginger', Canmap'Skewbald', Шағыр'Chalky';

- names defining temper of a horse: Йылғыр'Quick', Сығынсы 'Restive', Юртак'Trotting', Юpғa'Ambler', Ялкау'Lazy';

- $\quad$ names pointing to the month when the horse was born: Mapm - March, Anрель - April;

- names defining the external features: Акбәкәл'White old woman', Акморон'White snout', Акъял'White mane', Бөзрә ял ‘Curly crest';

- names defining generic assignment of a horse: Ерән айғыр'Ginger stallion', Кола бейә'Roan mare’.

- Function of names is performed by common nouns of different lexical-semantic group. They can be divided into the following groups:

- birds' names: Бөркөт 'Golden Eagle', Аккош'Swan', Күгәрсен ‘Dove', Карлуғас'Swallow', Карсыға'Hawk', Карға'Crow', Торна 'Crane';

- zoonyms: Aйыy'Bear', Ишәк'Conkey', Йәтсә'Vair', Йылан'Snake', Куян'Hare';

- phytonyms: Алма'Apple', Карбуз'Watermelon', Күрән'Ling'; 
- cosmonyms: Йондоз̧'Star', Сулпан 'Venus';

- toponyms: Байкал - Baikal, Дим - Dim, Урал - Ural, Иран - Iran;

- anthroponyms: Ахун, Гөлбикә, Райхан, Салауат;

- ethnonyms: Сыyau'Chuvash', Үзбәк'Uzbek';

- names formed based on many lexical groups: Алмас'Diamond', Оскон'Spark', Ялкын'Flame', Мендәр 'Pillow'.

The biggest part of Bashkir zoonyms make native Bashkir words of Turkic origin. Separate groups of animal names can be found in ancient Turkic inscriptions. Most of these items are not subjected to large changes. Changes occurred in the phonemic structure of words, but the roots remained unchanged. Let us pay attention to the following examples:

a) ̈küz ađaqï bolyïnča buzaүu başï bolsa jeg (өкүз аз̧акы болғынча бузағу башы болса йег) - үгез аяғы булғансы, быз̧ау башы булһаң якшырак'it is better to a leg of a bull than a head of a calf' (The Old Turkic Dictionary, P. 14);

b) alin arsla ntutar küčin sičyan tutmas (алын арслан тутар күчин сычған тутмас) - алдаксы арыс̧лан тотор, көслө сыскан да тотмас̧'a deceiver (a cunning one) may catch a lion, a strong one will not catch a mouse' (The Old Turkic Dictionary, P. 31];

c) jarïda böri ulïsa evdä ït bayrï tartišur (ŭарыда бөри улыса эвдә ыт бағры тартышур) - яланда бүре олоһа, өйзə эт бауыры тартышыр'if a wolf howls in the steppe, dogs will be scared even in the house' (The Old Turkic Dictionary, P. 78).

As shown by the above materials, names of animals that operate in the modern Bashkir language (өкүз үгез̧'bull', бузағу - быззау'calf', арслан - арысслан'lion', сычған - сыскан'тоuse', бөри - бүре'wolf', ыIm - эт'dog'), remained unchanged, and the transformations are observed only in the phonemic formation of these lexemes.

Bashkortostan territory is the habitat for about three hundred bird species. The motive for the naming the birds were the signs of their colour, voice, character growth, as well as their habitats. Many of the existing names of birds were not included in the Bashkir literary language and not all the ornithonyms are reflected in the lexicographical works. The dictionary by T. G. Baishev on zoology terms covers about 150 names of birds. Many of them are copied from the Russian language (Baishev, 1952).

E. F. Ishberdin defines the following types for naming birds (Ishberdin, 1986).

1. Colour of feathers: аккош, ак сарлак, ак ала таштурғай, буз тумыртка, йәшелғош, күк күгәрсен, кара каз. The components of these names are the following lexemes: aк'white', бyз̧'light grey', йәшел'green', күк'blue', кара'black', кызыыл'red', сыбар'stripped', hopo'brown'.

2. Bird's habitat (river, sea, village, bog, forest, steppe, shore): ауыл карлуғасы, басьыу көйгәнәге, диңгез бөркөтө, йорт турғайы, йылға безелдәге, йылға сарлағы, кала карлуғасы, камыш тауығы, еtс.

3. Names formed by assimilating parts of the body of birds to other subjects: балғабаш, без̧сукыш, берғаз̧ан, бүрекле тебейек, бүрекле һабан турғайы, бөзрә аккош.

2. Names pointing to the peculiarities of feeding: ала себен турғайы, балыксы турғай, кор карсығаһы, куян ябалағы, мышар баржылдағы, мышар турғайы.

3. Names pointing to the habits of life, the way of movement: балылксы турғай, баян кош, бейеүсе таштурғай, буран турғайы, борғандак, кесерткән турғайы.

4. Ornithonyms pointing to teh size of a bird: вак ала тумыртка, вак карабаш сарлак, вак карсыға, вак мөншөгөр, вак сарлак, вак себен турғайы, вак сәпсәү.

5. Names of birds expressing the character of sounds made by birds: баркылдак, безелдәк, заркыуыт, керелдәк сарлак, керелдәк сөрәгәй, көгөрләуек, кәкүк.

Thus, motivational signs of names of birds may vary. Productive features were such features as the colour of feathers, habitat, and character of sounds made by birds.

\subsection{Bashkir urbanonymics}

Despite the abundance of research in national onomatology, Bashkir urbanonymics as a holistic system does not receive enough study. Bashkir urbanonymics is characterized by common features urbanonyms, but at the same time, national and cultural characteristics of the Bashkir names of urban facilities shall be noted. National distinctness in urbanonymics is shown in use as names of lexical units of a language of the indigenous population, in reflection of national history, ethnography, and cultural achievements in the urbanonyms. Urbanonyms are characterized by dynamics and the ability to be updated, a combination of old and new. Most stable names are, in our opinion, the names of city streets. The analysis of linguistic facts shows that the change of socio-political system is not so clearly reflected in the names of 
streets.

The urbanonymics material chosen by us included the names of streets, or rather, godonyms of the Sterlitamak city, as these names of city objects reflect the majority of urbanonyms' qualities, and they are formed by the same principles of the nomination (Karabaev et al., 2013).

Sterlitamak is the second largest city in the Republic of Bashkortostan. It is developing dynamically in all sectors. There are new objects, causing the need for their names. This applies particularly to the streets and roads network of Sterlitamak. Currently, we have recorded 470 godonyms. As a result, the lexical-semantic classification of godonyms in the city of Sterlitamak was divided into three groups:

1. Reflection of the world of plants and landscape features in the godonyms. This lexical-semantic group of street names can be divided into the following criteria:

a) godonyms with hydrographic terms: Йылға урамы'Rechnaya (River) Str.', Шишмә урамы'Rodnikovaya (Spring) Str.';

b) godonyms related to the objects of nature: Урман урамы'Lesnaya (Forest) Str.', Болон урамы'Lugovaya (Meadow) Str.', Бас̧ыу урамы'Polevaya (Field) Str.';

c) godonyms reflecting the natural features:

- colour features: Йәшел урам 'Zelenaya (Green) Str.', Кызыыл урам'Krasnaya (Red) Str.';

- landscape features: Ситке урам'Kraynyaya (Outermost) Str.', Текә урам'Krutaya (Steep) Str.', Түбәнге урам'Nizovaya (Lower) Str.';

- light features: Аяз̧ урам'Yasnaya (Fair) Str.', Кояшлы урам'Solnechnaya (Sunny) Str.', Аяз̧ тылрыл 'Yasnyy (Fair) Lane', Якты урам 'Svetlaya (Light) Str.';

- location features: Урау урам 'Obiiezdnaya (Bypass) Str.', Kүсеу урамы'Pereezdnaya (Roadcrossing) Str.', Арқыры сығыу урамы'Perekhodnaya (Cross-over) Str.';

- sound features: Tымык урам'Spokoynaya (Calm) Str.', Tыныс урам 'Tikhaya (Quiet) Str.';

- reflection of other features: Тупик урамы'Tupikovaya (Dead-End) Str.', Үзəк урам'Tsentralnaya (Central) Str.', Яңы урам'Novaya (New) Str.', Яғымлы урам'Privetlivaya (Welcomable) Str.'.

As shown by the examples, the Sterlitamak godonyms point to different features of the objects.

2. Reflection of names of ethnic groups, social classes, the names of professions and crafts in godonyms. The names of streets in the city of Sterlitamak reflect the different spheres of human existence. This group includes the following godonyms:

a) names reflecting the ethnic groups: Башкорm урамы'Bashkirskaya (Bashkir) Str.', Белорус урамы'Belorusskaya (Belorus) Str.', Славян урамы'Slavyanskaya (Slavic) Str.'.

b) names reflecting professions and occupations: Космонавтар урамы'Kosmonavtov (Cosmonauts) Str.', Таусылар урамы'Gornyakov (Mine Workers) Str.;

c) godonyms reflecting social groups: Халыљ урамы'Narodnaya (People's) Str.', Йәштәр урамы'Molodezhnaya (Youngster's)Str.', Пионер урамы'Pionerskaya (Pioneer) Str.'.

3. Godonyms formed from anthroponyms. This group of godonyms accounts for the largest part of urbanonyms of Sterlitamak. Most anthroponyms performing the function of godonyms are names of famous and well-known personalities who have become famous in various spheres of public life. Anthroponymic street names consist of the following subgroups:

a) godonyms associated with the names of well-known people of the pre-October period: Айвазовский урамы'Aivazovsky Str.' (Aivazovsky Ivan Konstantinovich, 1817 - 1900; famous Russian painter, marine painter, battle painter, collector); Акмулла урамь'Akmulla Str.' (Kamaletdinov Miftakhitdin Kamaletdinovich, 1831-1895; Bashkir poet, poet-enlightener);

b) godonyms connected with the names related to the October events of 1917: Блюхер урамь'Blukher Str.' (Vasiliy Konstantinovich Blukher, 1890 - 1938; state and military chief, Marshall of the Soviet Union); Зәки Вәлиди урамы'Zaki Validi Str.' (Validov Akhmetzaki Akhmetshakh, 1890 - 1970; the leader of the national liberation movement, turcologist, Doctor of Philosophy, Honourary Doctor of the University of Manchester);

c) street names related to the events of the Great Patriotic War (World War II)) Авдошкин урамы'Avdoshkina Str.', (Avdoshkin Semion Egorovich, 1918 - 1963; Hero of the Soviet Union); Гайдар урамы'Gaidar Str.' (Golikov Arkadiy Petrovich, 1901 - 1944; Russian writer, participant in the Great Patriotic War (World War II));

d) godonyms associated with the names of prominent people who received recognition in different areas: Водолаженко урамь'Vodolazhenko Str.' (Vodolazhenko Georgiy Ivanovich, manager of the multicorporate enterprise "Sterlitamakstroy"); Мостай Кәрим урамы'Mustaya Karima Str.' (Karimov Mustafa Safich, 1919 2005; Bashkir Soviet poet, writer and dramatist, National poet of BASSR). 
Godonyms formed as a result trans-onymization of anthroponyms form the basic reserve of street names in Sterlitamak. This group of street names associated with the names of prominent people, reflects the history, the ethnic composition of the population and the cultural achievements of the country and the region.

4. Godonyms, associated with industry and other areas of economic life: Механизация урамы'Mekhanizatsii (Mechanisation) Str.', Трансnорm урамы'Transportnaya (Transportation) Str.', Дuсnетчер урамы'Dispetcherskaya (Dispatcher) Str.'.

5. Godonyms formed based on macro-toponyms and hydronyms. The names of the streets in this group reflect the names of major geographical and water bodies:

a) Hydronyms subject to trans-onymization: Ашказ̧ар урамы'Ashkadarskaya (Ashkadar) Str.', Амур урамы'Amurskaya (Amur) Str.';

b) Toponyms transferred into godonyms: Бәләбәй урамы'Belebeiskaya (Belebei) Str.', Белорет урамь'BReloretskaya (Beloretsk) Str.', Брест урамь'BBrestskaya (Brest) Str.';

c) Godonyms formed based on oronyms: Кавказ урамь'Kavkazskaya (Caucausian) Str.', Джамбул урамы'Dzhambulskaya (Jambyl) Str.', Урал урамы'Uralskaya (Ural) Str.'.

\subsection{Bashkir phytonymy}

This layer of onomastic units and derivational morpheme signs can be divided into the following groups:

- $\quad$ non-derivative phytonyms: андыз̧ 'elf dock', балан'arrow-wood', бойз̧ай 'wheat, курай'salt grape', мүк'mоss';

- simple derivative phytonyms: hөтлөгән 'еuphorbia', һырлан 'blue bur', күксин 'iliac';

- complex phytonyms: алтьнбаш'European goldenrod', болануm'French willow', көнбағыш'sunflower', куянтубык'chervil', тилебәрән 'henbane'.

Complex phytonyms are formed using the following onomastic units:

- zoonyms: дөйә hеңере'locoweed' (дөйә'camel)', бесәй табаны'catspaw', күгәрсен күз̧е'forget-me-not' (күгәрсен'dove)' карға күз̧е'Paris herb';

- toponyms: америка сағаны'box elder', себер шыршыһы'Siberian spruce', урал актамыры'quick grass';

- mythonyms: шайтан таяғы'thistle';

- kinship terms: кейәу үләне 'thyme' (кейәү'son-in-law'), угәй инә үләне'foalfoot'.

The basis for the name can be the colour of the plant: ак 'white': ак ерек'speckled alder', ак томбойок'Madonna lily', ак әрем'white wormwood'; күк'blue': күк умырзая'wind flower; кара 'black': кара бороc'black pepper', кара бөрлөгән'blackberry', кара карағат'black currant'; кызыыл 'red': кыззыл бөрлөгән'stone brambleberry', кызыыл карағат'red currant'; hары 'yellow': haрыгүз̧'European centaury', hapығат'sandthorn' hapы мәтрүш'John's wood', hарысай'helichrysum', hapы умырзая'spring adonis'.

In some cases, phytonyms serve as a basis for the formation of new onomatology units. The result of transonymization is their transition into anthroponyms: For example: Зәйтүнә - Zaituna'green olives', Ләлә - Lyalya'lily', Миләүшә - Milyausha'violet', Нәркәс - Narkas'joquil' Әнисә - Anisa'anise'.

The language contains the facts of transition of the plants' names into toponymic units: Ерек - Erek'alder', Камыш - Kamysh 'reeds', Курай - Kurai 'Pleurospermum uralense' (hydronyms), Карағай - Karagaievo'pine' (placename).

Thus, the phytonymic lexicon is characterized by the same features as the other onomatology units.

\section{Discussion}

In the modern period in the Bashkir linguistics, there are a number of scientific papers on the problems of onomatology. Some of the findings and the position obtained in these studies were the theoretical basis of the study.

Because of a comprehensive study of onomastic space of the Bashkir language, we obtained the results of the following nature:

1) Research interest in the phenomena of onomatology from the representatives of some of the humanities is explained by the desire to use lexical units not only to learn the language and its history, but the history of the people, their ethnic and cultural development;

2) The Bashkir onomatology, to date in scientific terms has no considered and investigated categories such as cosmonyms, zoonyms, mythonims, phytonyms, urbanonyms, and nicknames, and not revealed the role of onomastic units in the creation of the Bashkir language picture of the world;

3) The basic lexical fund of the Bashkir onomatology make native Bashkir words of Turkic origin. In addition, it is represented by tokens borrowed from other languages; 
4) In terms of the historical approach, the ancient personal names are the names that indicate the outward sign of the child;

5) The Bashkirs to the XVI century did not use family names. Bashkir family names are formed by the scheme of Russian last names;

6) The function of nicknames in the Bashkir language belongs to the words of different lexical-semantic group;

7) The largest portion of urbanonyms is made up of anthroponymic godonyms;

8) Bashkir onomatology features with the observed transition from one category to another. Using transonymization, lexical units in the formal respect are not affected.

\section{Conclusion}

Bashkir onomatology is diverse and multidimensional in its material component of the fund, according to the semantic organization of origin, on the relationship of literary language and dialects. The study of the Bashkir onomatology, being closely associated with the history and life of the people, has value in terms of reflecting the dynamics of life, the evolution of consciousness and innovation life.

In this article, we discussed the main sections of the Bashkir onomatology. Nevertheless, there remain some open questions regarding this section of the Bashkir linguistics. In the future, we expected to further in-depth study of such onomatology units as zoonyms, cosmonyms, phytonyms, and mythonyms. Linguistic analysis of the given onyms, in our opinion, helps to clarify some phenomena in the field of Bashkir onomatology, and in the field of ethno-cultural development of the people.

\section{Acknowledgements}

We would like to express special thanks to Ishbaev Karim Gaiseevich, the Professor of Sterlitamak Branch of the Bashkir State University for assistance in the investigation of this problem.

The study was conducted under the "Urbanonyms in the onomastic space of the Bashkir language" grant, provided by Sterlitamak Branch of the Bashkir State University.

\section{References}

Abdullina, G. R. (2004). Bashkir language. Morphophonology - Ufa: Gilem.124 p.

Baishev T. G. (1952). The dictionary of zoological terms. - Ufa. 120 p.

Baskakov N. A. (1979). Russian family names of Turkic origin. - M.: Nauka. 280 p.

Bukharova G. Kh. (2006). Bashkir onomatology in the context of spiritual culture. Dictionary of mythotoponyms. - Ufa: Gilem. $116 \mathrm{p}$.

Garipov T. M., Sirazetdinov G. B. (1976). Family names of the Bashkirs in the documents referring to XVII-XVIII centuries. //Onomatology of the Volga region: Proceedings of the IV conference on onomatology of the Volga region. - Saransk. - P. 129-132.

Kamalov A. A. (1994). Bashkir toponymy. - Ufa: Kitap. 304 p.

Khalitov R. Ya. (2002). Hydronymics of the Orenbirg region. Thesis research ... of the Candidate of Philosophical Sciences. - Ufa. 185 p.

Lasymova N. A. (2004). Oronyms of the Southeast Bashkortostan (linguistic analysis). Abstract of the thesis ... of the Candidate of Philosophical Sciences. - Ufa. 23 p.

Shakurov R. Z. (1986). On the trails of geographical names. - Ufa. -184 p.

Sirazhitdinov R. A. (2000). Bashkir ethnonyms: semantic-derivational analysis. Abstract of the thesis ... of the Candidate of Philosophical Sciences. - Ufa. $-26 \mathrm{p}$.

Uraksin Z. G. (1976). Bashkir names for horses //Onomatology of the Volga region: Proceedings of the IV conference on onomatology of the Volga region. - Saransk. - P. 309-313.

Usmanova M. G. (1994). The name of the paternal land. - Ufa. -272 p.

Башкорт теле. (2012). Юғары укыу йорттарының филология фракультеты студенттары өсөн дәреслек / Г.Р. Абдуллина, Г.Д. Вәлиева, К.Ғ. Ишбаев (яуаплы мөхәррир) һ.б. - Өфө: Кіtap. - 616 р.

Башкортостан: Кыс̧каса энциклопедия. - Өфө: Kitap, 1997. - 696 p.

Ишбаев К.Ғ., Абдуллина Г.Р., Ишкилдина З.К. (2006). Башкорт теленең морфемикаһы, һүзьяһалышы һәм морфоонологияһы. Өффө: Ғилем. - 150 р.

Ишбирзин Э.Ф. (1986). Башкортостан коштары. - Өфө: Kitap. - 168 р.

Карабаев М.И. (2008). Башкорт теленең ономасиологияһы. - Стәрлетамак: SGPA. - 139 р.

Кусимова Т.Х., Бикколова С.Ә. (2005). Башкорт исемдәре.- Өфө: Кitap. - 224 р.

Сөләймәнова Р.Ә. (2006). Хәз̧ерге башкорт телендәге антропонимдар һәм уларзың үс̧еш тенденциялары. - Ufa. 148 p.

Хисамитдинова Ф.Ғ., Төпәйев С.Х. (2006). Төрки сығанаклы һәм төрки элементлы башкорт исемдәре.- Өфө. - 120 р. 